\title{
Corruption and Reversal Burden of Proof
}

\author{
Dr. Wahyu Wiriadinata \\ Lecturer, Faculty of Law, University of Pasundan \\ Korespondensi mengenai artikel ini harus dialamatkan kepada \\ Wahyu Wiriadinata, Jl. Idi Adimaja I No. 1 Bandung \\ E-mail: wahyuwiriadinata@yahoo.co.id
}

Accepted: March 13, 2014

Doi:10.5296/ jpag.v4i1.5447 URL: http://dx.doi.org/10.5296/ jpag.v4i1.5447

\begin{abstract}
This paper, entitled Corruption and Reversal Burden of Proof, was intended to deal with a question on the extent of the effectiveness of a reversal burden of proof as stipulated in positive (applicable) Indonesia law, that is, as provided for in Law Number 31 of 1999 on Eradication of Corruption Crime. Then, a problem that rose next was: could the application of reversal burden of proof in proving a corruption crime case prevent or reduce or even eliminate totally corruption crimes in Indonesia? This research built on a theoretical frame of thought from Roscoe Pound, who maintains that law is a tool of social engineering. This concept was cited by Muchtar Kusumaatmadja, who adapted it to Indonesia conditions and adjusted it to be law as a social engineering medium. Engineering is meant here as a transformation of the thinking ways of people from traditional thinking ways to modern ones. Law should be made as a means in resolving the entire problems that emerge between and among community, including corruption crimes. One of the things that need to be changed is a law of proof law system, that is, from a conventional proof system to be a reversal one. This paper was written by a juridical-normative method, that is, by studying legislations, be they are contained in laws and those contained in literature/books on legal science, particularly legislations related to reversal burden of proof. Then, the results, in a form of juridical aspect, were written in a descriptive-analytical form. The overall conclusion of this research was an answer of the problems posed above, that is: Corruption crimes have been continuously occurring till now in Indonesia. Thus, Law Number 31 of 1999, particularly Article 37, has not been effective yet in eradicating corruption crimes.
\end{abstract}

Keywords: Corruption, reversal burden of proof, limited reversal burden of proof 


\section{Introduction}

The school of natural law, as Aristotle ( \pm 300 BC), a disciple of Socrates, puts it, provides a direction on the goals of law. According to natural law, the main goal of law is to realize the ultimate, essential goal of community, that is, justice. However, before it can be accomplished, an order in the community should be firstly created. Without an order there will be no a sense of justice in a community.

Indeed, the goal of law is not only to achieve a justice but also legal certainty, as suggested by recht positivism or school of positive law that evolved in $19^{\text {th }}$ century, the leading advocate of which is Hans Kelsen (1881-1973). However, the former is the main, oldest goal of law that is still maintained till now, provided that an order should be firstly created in the community.

In line with the preceding description, Muchtar Kusumaatmadja offers a definition of law as follows:

Law is the whole principles and norms that regulates the associations of human lives in community that is intended to keep order and to achieve justice, also involving institutions and processes that realizes the implementation of the norms as a reality in community. ${ }^{1}$

From the definition above it is obvious that, according to Muchtar Kusumaatmadja, an essential goal of law is the keeping of order and the realization of justice. To achieve the latter, the former should be created in advance.

A justice can be enforced by a trial process. In Indonesia, trial is a process in criminal-law procedural code. It begins with an investigation by investigators (police, prosecutor, KPK), pre-prosecution by public prosecutor, prosecution and hearing before a court by a public prosecutor and judges, legal remedies (appellate, cassation, judicial review), and the execution of verdict by a public executor and also implementation of legal procedures during a convict is serving his or her sentence at a Penitentiary.

A normative trial process should refer to prevailing provisions according to legislations. However, trial processes very often deviate from the required paradigm. The deviations in trial processes may happen by employing corruption, collusion, or nepotism modes. Such modes may vary widely and they are often employed by wrongdoers. One of the modes is a corruption by law enforcers, augmenting the list of corruptors in Indonesia.

Corruption, collusion, and nepotism are one of the causes for the fall of Soeharto's New Order regime. The collapse of New Order regime gave a rise to another order, Reformation Order. It is during the Reformation Era that Government shows a political will, that is, a determination to eradicate corruption, because corruption is a crime the eradication of which is extremely complicated, hence an extraordinary crime. Its eradication needs extra measures.

Corruption crime is a legacy of Old Order and New Order, even far before, that is in the days of VOC (Verrenige Ost Indische Company). Its classic cause is bribery and ceremonial cultures that proliferates corruption in Indonesia. However, in post-independence, particularly since New Order era, there have been some contemporary causes of corruption crime to 
underscore, some of which will be briefly outlined below.

\subsection{Legislation aspect}

Positive legislation/laws in Indonesia are still weak, because some of them are the products of Dutch colonial regime. Of course, such legislation/laws don't accommodate the aspirations of contemporary Indonesia people, because they were enacted by Dutch government, in Netherlands, and have been out of date. Accordingly, they are very un-inspirative to the will of Indonesia people/nation.

The prevailing legislation on corruption, collusion, and nepotism $(\mathrm{KKN})$ don't fully reflect the aspiration of Indonesia people. For example, legislation on "reversal burden of proof", because the reversal burden of proof as provided for in article 37 of Law on Corruption is not a pure reversal burden of proof, but rather a limited one, so that it lacks of deterrent power in preventing anyone from committing a corruption.

\subsection{Law Enforcer Aspect}

There are three pillars of law enforcers in Indonesia in a context of an integrated criminal justice system, namely, investigators (police/prosecutor/KPK), public prosecutor, and judge. The three law enforcers are the forcing instrument of the implementation of legislation.

Even if the materials of KKN laws have been adequate (kaffah, capable, aspirative) they will be practically meaningless if they were not applied properly by the law enforcers. That is, good as legislation may be, its objective would not be accomplished if its forcing instrument/enforcers don't implement it properly.

Law enforcers as the enforcing instrument of legislation should, in implementing a law, be of personal integrity, fair, and honest. However, such quality has not been possessed fully yet by those law enforcers who commit deviations in implementing their duties as law enforcers. This is due to, among others, low personal integrity, insufficient human resource, and less-than-minimum standard prosperity level.

\subsection{Awareness/law obedience of community aspect}

Law awareness/obedience of community as described above has been at a lowest point. This phenomenon is very unfavorable for the emergence of qualified law enforcers and justice and for the substance of corruption eradication. A good legislation applied by equally good law enforcers (as the enforcing instrument of the implementation of law), would be meaningless if they were not supported by the legal awareness of community. The law obedience of community (as the subject that should comply with the norms contained in laws/legislation) should be enhanced.

Corruption culture as indicated above develops because, among others, the fading of a sense of shame among community, including those public officers who commit corruption crimes.

Therefore, in the context of corruption eradication, the culture a sense of shame should be revived among our people to discourage them from committing corruption. This can be done by socialization measures, such as education, extension, and information spreading that 
reaches not only public bureaucrats, political elites, and law enforcers but also the youths. Since children attend kindergarten such education, extension, and information spreading should be initiated.

Besides from the three aspects above, exemplary behaviors aspect should highlighted, that is: there should be exemplary behaviors that officers, particularly bureaucrats, show in their daily life. Thus far, there is a stigma in bureaucrat circle that many bureaucrats are hedonistic and consumptive in their daily life. Therefore, exemplary behaviors by bureaucrat should be displayed, in which bureaucrats should be modest in their daily life so that community would imitate the behavior. This may reduce or prevent corruptions.

Reformation Order administration has taken seemingly optimal measures against the three causes of corruption above, but in fact corruptive behaviors and corruption crimes are even increasingly rampant. Therefore, in Reformation Order, a super body institution that has an authority to eradicate corruption outside the existing law enforcers (attorney and police), that is, Corruption Eradication Commission (KPK) is created (Law Number 30 of 2002).

However, after KPK has worked for nearly ten years, it turns out that both corruptive behaviors and corruption crimes are increasingly rampant. In addition, it appears that, over time, the measures KPK takes have resulted in not only political consequences but also political ones, especially to public officers and bureaucracy. Some measures Indonesia Government took have given a rise to a bureaucratic chaos phenomenon. Many decision makers are afraid to make any policy for providing services to public, resulting in stagnation.

The government has apparently been desperate in eradicating the already entrenched corruption.

Corruption problems are always actual. Thus, we should continuously search for a way out, how to properly resolve them.

There is one method the Indonesia government and people have not pursued yet in eradicating corruption, that is, by applying a reversal burden of proof. This is a discourse to apply in a (pure/absolute) proof of corruption crime. This discourse is interesting to study.

From the description above, there are some problems identified. One problem put forward in this work was: To the extent of which the effectiveness of reversal burden of proof as provided for in Indonesia positive laws, that is, as stipulated in Law Number 31 of 1999 on Corruption Crime Eradication? Another problem was: Can the implementation of reversal burden of proof in the proving of corruption crime cases (as stipulated in Law Number 31 of 1999) prevent or reduce or even eliminate corruption crimes in Indonesia?

The objective of this work was to find out to the extent which Law Number 31 of 1999 on Corruption Crime Eradication, particularly Article 37, has stipulated the principles of reversal burden of proof. The intended reversal burden of proof is a pure or pseudo one. The benefit of this work was theoretical in nature, that is, it is hoped that it would be beneficial for legal science, particularly formal criminal law/procedural law.

This work was prepared by using a juridical-normative method, that is, by studying 
legislations contained in laws and those contained in legal literature/science books, particularly legislations related to a reversal burden of proof. Then, the findings in form of both juridical and sociological aspects were written in a descriptive-analytical form.

This work also proposed a thought, that the main goal of law is to realize justice in community, in addition to realize the legal certainty, as intended by Rechts Positivisme School advocated by Hans Kelsen. The former is the oldest goal of law that is still maintained till now, provided that an order should be firstly created in the community.

In line with the preceding description, Muchtar Kusumaatmadja offers a definition of law as follows:

Law is the whole principles and norms that regulates the associations of human lives in community that is intended to keep order and to achieve justice, also involving institutions and processes that realizes the implementation of the norms as a reality in community. ${ }^{2}$

From the definition above it is obvious that, according to Muchtar Kusumaatmadja, an essential goal of law is the keeping of order and the realization of justice. This corresponds with Roscoe Pound's thought. Moreover, Roscoe Pound proposes a notion of law as a tool of social engineering. This concept was cited by Muchtar Kusumaatmadja, who adapted it to Indonesia conditions and adjusted it to be law as a social engineering medium. Engineering is meant here as a transformation of the thinking ways of people from traditional thinking ways to modern ones. Law should be made as a means in resolving the entire problems emerging between and among community, including rampant corruption crimes. One of the things that needs to be changed is the system adhered by criminal-law procedural code, that is, from a conventional proof system to be a reversal one. Is it possible to apply in Indonesia?

\section{Proof System or Theory}

The proving of whether or not it is true and convinced that the defendant has committed any crime as accused in the prosecution of prosecutor is the most important part in a criminal-law procedural process. What is the consequence if the defendant is found guilty by judges, whereas in fact he or she is innocent? Criminal-law procedural code is intended to reveal a material truth.

There are some systems or theories to prove an accused crime. The systems or theories of evidence vary with times and places.

Indonesia and Dutch and other continental Europe countries share a practice that it is judged, not jury as practiced in United States and Anglo-Saxon countries, who decide on the evidence presented. In the latter countries it is jury who decide on whether the defendant is either guilty or not guilty, whereas judges only chair the session and decide a sentence.

Seeking a material truth is not an easy task. Evidence means, such as testimony, are often ambiguous and very variable. Testimonies are presented by forgetful persons. According to psychology, different persons will convey different accounts on the same occasion. A survey was conducted in a Swedish school. The students had been gathered together in a classroom, and then a guest came into the classroom a moment and then went out. Asked on the color of 
dress the guest worn, the children answered differently. Some said blue, another gray, still another brown.

Therefore, in earlier times it was widely accepted that the most reliable evidence is the confession of the defendant, because it is he himself or she herself who underwent the occasion. Then, the confession of the defendant was sought in trial, which may satisfy the judges, being considering that material truth has been found.

It is for a reason of seeking material truth that accusatoir principle, viewing the defendant as the defendant in civil case, was abandoned and replaced with inquisitoir principle, viewing the defendant as the object of trial. The latter principle is even employed to obtain the confession of the defendant.

In judging the proving power of existing evidence means, there are some proof systems or theories.

\section{a. Positive Law-Based System or Theory of Proof (Positief Wettelijk Bewijstheorie)}

A proving based on the evidence means as specified in laws is called positive law-based theory of proof (Positief Wettelijk Bewijstheorie) ${ }^{4}$. It is said 'positive' because it is based exclusively on law. That is, if an crime has been proven according to the evidence means specified in law, then the conviction of judge would no longer needed at all. This system is also called as a formal theory of proof (formale bewijstheorie).

That theory of proof is now already abandoned. It relies too much on the evidence power as specified in laws.

\section{b. Exclusively Judge Conviction-based System or Theory of Proof}

In contrary to a positive law-based theory of proof is a theory of proof according to judge conviction. This theory is also called conviction intime.

It is recognized that an evidence means in form of the conviction of the defendant does not always prove the truth. It occasionally does not assure that the defendant has actually committed the accused crime. Therefore, the conviction of judge is anyway needed.

It is based on the rationale that the theory of judge conviction considers that the defendant has committed the accused crime if the judge is convinced on it. By this system, punishment is allowable without being substantiated by statutory evidence means. This system is applied by jury trial in French.

Such proof system has ever been applied in Indonesia, that is, in district and regency courts. The system makes it possible for judges to say at will whatever the basis of his or her conviction, including paranormal prophecy.

In earlier times, customary and autonomous local courts also applied the conviction of judges, given that the courts were staffed by judges with no training (education) in law.

The system delegates too wide discretion to judges, so that they are hard to supervise. In addition, the defendant or his or her attorney is hard to prepare defense. Under the condition, 
judges may find the defendant guilty based on their conviction that the defendant has actually committed the accused crime. Jury trial practice in France applies the method and it results in many odd, justice-offending acquitting decisions.

\section{c. Judge Logical Conviction-Based System or Theory of Proof (Laconviction Raisonnee)}

As a solution, a system or theory called a proving that is based, up to a certain limit, on judge conviction (la conviction raisonnee). The theory conceptualizes that judges may decide the bases of proving together with conclusions (conclusie) based on certain proving legislation.

The system or theory of proof can also been called a free proof because judges are free in stating the bases of their conviction (vrije bewijstheorie). The middle-way system or theory of proof or one that is based, up to a certain limit, on judge conviction is divided into two. One is a judge logical conviction-based theory of proof (conviction raisonnee) and another is negative law-based theory of proof (negatief wettelijk bewijstheorie).

The similarity between both theories is that they are based on judge conviction, meaning that the defendant would not be punished without the judges is convinced that he or she is guilty.

The difference between both theories is that the former is based on judge conviction but the conviction should be based on a logical conclusion (conclusie), not on provisions according to the judge knowledge, depending on his or her preference on the implementation of which proof system he or she would apply. The latter is based on the proving rules as stipulated with limitations by law, but it should be accompanied by judge conviction.

It could be concluded that there are two differences; one is based on judge conviction, another on statutory provisions. Moreover, in the former the basis is a conclusion that is not based on law, whereas in the latter is based on statutory provisions that are applied with limitations.

\section{d. A Negative Law-Based Theory of Proof (Negatief Wettelijk)}

Both HIR and KUHAP apply a negative law-based system or theory (Negatief Wettelijk). This can be seen from Article 183 KUHAP, formerly Article 294 HIR.

Article 183 KUHAP reads as follows:

"A judge cannot hand down a sentence to anyone, except that, by at least two valid evidence means, he or she is convinced that a criminal crime has actually occurred and that it is the defendant that is found guilty of committing it."

From the provision above it is evident that proving should be based on law (KUHAP), that is, the evidence means specified in Article 184 KUHAP, substantiated by judge conviction derived from the evidence means.

The article above parallels the provisions contained in Article 294 paragraph (1) HIR that reads as follows:

"No one can be sentenced criminally, except that the judge is convinced with valid evidence 
means, that there has actually occurred a punishable crime and that it is the accused persons who are found guilty of committing it".

In fact, before the enactment of KUHAP, a similar provision had been contained in Basic Law on Judicative Power (UUPKK) Article 6 that reads as follows:

"No one can be sentenced criminally, except that the court, based on valid evidence means according to law, is convinced that someone who is liable has been found guilty for the crime accused on him or her."

A weakness of the formulation of this law is that it states evidence means that are valid according to law of evidence means, or as stipulated in Article 183 KUHAP that determines two evidence means.

In this negative law-based system or theory of proof (negatief wettelijk bewijstheorie), punishment is based on a double proof (dubbel en grondslag), namely, on legislation and on judge conviction, and according to law, the basis of conviction is legislation.

The latter is in line with Article 183 KUHAP, stipulating that, from the two valid evidence means, judge conviction is derived.

According to the author, conviction can only be based on the contents of valid evidence means (specified by law).

The official explanation of Article 183 KUHAP says that this provision is to ensure the triumph of truth, justice, and legal certainty for anyone.

The four proof systems above can be applied to all crimes, be they general and special crimes. On some certain crimes, a different proof system than the four systems, that is, reversal burden of proof can be applied.

\section{Reversal Burden Of Proof}

Reversal burden of proof (omkering van het bewijslast) is an adoption from Anglo-Saxon countries, such as England, Singapore, and Malaysia. In Indonesia, the study of reversal burden of proof produces a very comprehensive benefit, because one of the constraints in eradicating corruption crime is the difficulty in producing a proof of corruption crime. Based on an academic and practical research, it was found that the intention of applying the principle is not in a total, absolute context, but a comparative approach of the country which applies the principle. ${ }^{5}$

There has never existed a total, absolute reversal burden of proof, that is, it can only be applied by limitations, specifically on crimes of bribery-related gratification.

The provisions on bribery-related gratification say basically that public servants who receive, are paid for, or are given from and or by anyone, then the gratification shall be deemed as corruption, without otherwise proven. This applies a reversal burden of proof, but it is limited to crimes related to gratification and bribery, thus the reversal burden of proof of Anglo-Saxon countries, from which the system originates, is not absolute, specialized, and of 
limited scope.

\section{Reversal Burden Of Proof in Law Number 31 Of 1999}

As said before in this paper, Anglo-Saxon countries, as the origin of Reversal Burden of Proof, continuously requires the limited and exceptional nature of the system. Such requirement is applied in Law Number 31 of 1999.

What is intended by limited and specialized of reversal burden of proof in Law Number 31 of 1999 ?

Let us inquire the meaning of reversal burden of proof according to Article 37 of Law Number 31 of 1999 on Eradication of Corruption Crime, which reads as follows:

1) The defendant has a right to prove that he or she didn't commit the alleged corruption crime.

2) In case the defendant successfully proves that he or she didn't commit the alleged corruption crime, then the defense shall be utilized to favor him or her.

3) The defendant is required to provide the whole clarification on his or her properties and his wife's or her husband's properties and his or her children's properties and the properties of all individuals or corporations allegedly related to the court case under trial.

4) In case the defendant unsuccessfully proves his or her properties that are not proportional to his or her income or other sources of revenues, the clarification may be utilized to strengthen the already existing evidence means that the defendant has committed a corruption crime.

5) Under a situation as intended in paragraphs (1)-(4) above, general prosecutor remains to be required to prove his or her prosecution.

Moreover, the official explanation of Article 37 says that:

These provisions are a deviation from the provisions of Criminal-Law Procedural Code stipulating that it is prosecutor who is required to prove the doing of crime, not the defendant. According to this provision, the defendant may prove that he or she didn't commit the alleged corruption crime. If the defendant successfully proves it, it does not mean that he or she is proven as not guilty of doing the alleged corruption, because the prosecutor is still required to prove his or her prosecution. The provision of this Article is a limited reversal burden of proof, because prosecutor is still required to prove his or her prosecution.

From the content of the official explanation of Article 37 above it can be drawn a conclusion that the reversal burden of proof adhered by Article 37 of Law Number 31 of 1999 on Eradication of corruption crime is a limited reversal burden of proof, which is rarely practiced in daily corruption crime trial in Indonesia. It indicates that the system is still ineffective.

From the doctrine approach and a comparison of criminal law system (including Law 
Number 31 of 1999, Article 37 and its official explanation), the meaning of "limited" or "specialized" of the implementation of reversal burden of proof is as follows:

1. Reversal burden of proof is limited to only bribery-related gratification cases, and not to other crimes in corruption crimes.

2. The reversal burden of proof for other crimes in Law Number 31 of 1999 as contained in Articles 2 to 16 remains on prosecutor.

3. Reversal burden of proof is limited to only "confiscation" of crimes accused to anyone as contained in Articles 2-16 of Law Number 31 of 1999. It is also noteworthy that the proving system on the alleged offense in Articles $2-16$ of Law Number 31 of 1999 remains to be laid on prosecutor. If the defendant is, according to prosecution, considered as being proven to commit any of the offences and his or her properties are confiscated, then the defendant is required to prove that his or her properties are not originated from a corruption crime.

4. That the limited reversal burden of proof adheres to its Lex Temporis, that is, this system shall not be applied retroactively, being potential to violate human rights, to violate legality principle, and to induce so called Lex Talionis (retaliation).

5. That limited reversal burden of proof should not deviate from "Daad-daderstrafrecht". That is, the reversal burden of proof is strongly disallowed to violate the principal interests and rights of the doer (the defendant). That the implementation on the reversal burden of proof is an unavoidable condition, particularly the minimization of the rights. And if it occurs, it is said that the reversal burden of proof is potential to cause a violation of human rights.

\section{Reversal Burden of Proof on a Confistication of the Defendant's Properties}

Reversal burden of proof is applied to a confiscation of defendant's properties. That is, the defendant accused of committing any of the provisions of Article $2-16$ of Law Number 31 of 1999 is required to prove that his or her properties he or she gained before the alleged corruption crime had not originated from corruption crimes. The requirement of such property confiscation is made by the prosecutor during the presentation of prosecution on primary case.

This provision is a clarification of public misled opinion that suspects that reversal burden of proof is a new, potential basis of corruption for law enforcers, though such occurrence in not impossible. Reversal burden of proof is only applied to a newly adopted crime related to gratification. "Confiscation" is applicable to all corruption crimes that are stipulated in Articles 2-16 of Law Number 31 of 1999, that is, the application of reversal burden of proof should be preceded by a legal process of someone, whereas to violations of Articles 2-16 the conventional system of proof remains to apply (it is prosecutor who should prove). Thus, reversal burden of proof is not applied altogether on the crimes stipulated in Articles 2-16 of Law Number 31 of 1999, meaning that the burden of proof is on whether there has been a 
violation against Articles 2-16 of Law Number 31 of 1999 remains on prosecutor. However, if the prosecutor by a prosecution is convinced that the defendant had actually violated any provisions in Articles 2-16 of Law Number 31 of 1999 and the defendant's properties are confiscated, then the confiscation of the properties shall be processed by reversal burden of proof. It is only applied in court process, not in the course of investigation and prosecution. It is intended to accommodate inputs from public who concern on the occurrence of another corruptions (extortion and bribery), particularly if reversal burden of proof is applied in the course of closed investigatory and prosecutor processes.

The burden of proof on prosecutor is an absolute right of a defendant in form of presumption of innocence, which is in the same time to be a form of actualization of the acceptance of non self-discrimination principle, as the soul of KUHAP (Article 66).

In addition, according to Indonesia Criminal-Law Procedural Code, a defendant has a right of silence or not to answer any questions asked by judges or prosecutors.

The principle is a universal human rights protection principle, as contained in Universal Declaration of Human Rights 1948.

From the description above it can be seen that the implementation of the reversal burden of proof adhered in Article 37 of Law Number 31 of 1999 is ineffective and has no strong deterrent power to prevent persons from committing corruption crimes.

Some suggest that the reversal burden of proof applied in Indonesia should be a pure one, so that the system would be more effective in deterring corruption crimes in Indonesia. Such suggestion is apparently understandable. However, it should be noted that the application of such system would violate legal principles that prevail universally, including in Indonesia, such as presumption of innocence principle and non self-discrimination principle, and it is also a violation against human rights and the right of silence of the defendant as stipulated in Article 66 of KUHAP. In addition, the application of a pure reversal burden of proof would potentially result in new chances of corruption, particularly by law enforcers. Furthermore, the application of the system would be of political impact that influences the affairs of nation, because it is worried that the application of the system would result in a bureaucratic chaos. ${ }^{7}$

\section{Conclusion}

1. Corruption crimes in Indonesia have been occurring till now, even at an increasing intensity, both in quality and in quantity. Thus, Article 37 of Law Number 31 of 1999, as a means of eradicating corruption crimes, has not been effective yet.

2. To prevent and overcome corruption crimes in Indonesia and to eliminate them, or at least to reduce them, both in quality and quantity, a juridical approach is not enough, but rather it also needs a sociological and political approach. Particularly in dealing with corruption crimes, criminal-law procedural code related to their resolution should be applied as effective as possible. It is not sufficient by applying a conventional system of proof, but apparently a pure reversal burden of proof should be applied. However, the implementation of a pure reversal burden of proof may result in violations against 
presumption of innocence and non self-incrimination principles, violations against human rights and right of silence, as well as results in bureaucratic chaos.

Bandung, May 2013

\section{Bibliography}

Adji, Oemar Seno. 1976. Hukum (Acara) Pidana dalam Prospeksi, Jakarta. Erangga.

Andi Hamzah. 2006. Hukum Acara Pidana Indonesia, Jakarta. Sinar Grafika.

Barda Nawawi Arief. 1996. Bunga Rampai Kebijakan Hukum Pidana, Cetakan Kesatu. Bandung, Penerbit PT. Citra Aditya Bakti.

Bonn, E. Sosrodanukusumo. Tt.t, Tunutan Pidana. Djakarta: Penerbit "Siliwangi”.

Prodjodikoro, Wirjono. 1967. Hukum Atjara Pidana di Indo. Djakarta : Penerbit "Sumur Bandung”.

P. Sitorus, 1998. Pengantar Ilmu Hukum (dilengkapi tanya jawab, Pasundan Law Faculty. Bandung. Alumnus Press.

Roscoe Pound, 1972. Pengantar Filsafat Hukum, Jakarta. Bharata.

Saleh, Roelan. 1983. Mengadili Sebagai Pergaulan Kemanusiaan. Jakarta : Aksara Baru.

Soedjono D. 1982. Pemeriksaan Pendahuluan Menurut KUHAP. Bandung: Alumni.

Tahir, Hadari Djenawi. 1981. Pokok-Pokok Pikian dalam KUHAP. Bandung: Alumni.

Tanusuboto. S. 1983. Peranan Praperadilan dalam Hukum Acara Pidana. Bandung : Alumni.

Tresna, R. tt.. Komentar HIR. Djakarta: Pradnya Paramita.

\section{CURRICULUM VITAE}

Full Name $\quad$ : Dr. H. Wahyu Wiriadinata, S.H., M.H.

Place of birth : Bandung, Indonesia

Date of birth : 21 October 1950

Address : $\quad$ Jl. Idi Adimaja I No. 1 Bandung, Indonesia.

Occupation : - Lecturer for Post Graduate Program Padjadjaran University, Bandung. -Lecture for Faculty of Law Pasundan University, Bandung. 